\title{
STRENGTHS AND CHALLENGES OF FEDERAL GOVERNANCE IN NEPAL: RE THINKING WITH RURAL DEVELOPMENT APPROACH
}

Bhattarai Naba Raj ${ }^{3 *}$

\begin{abstract}
Rural development in Nepal is a complex phenomenon. It is an interaction among economic, social, political and cultural factors. The concept of rural development is a process of wholistic development and change to improve rural livelihood. Rural development is linked with infrastructural development, commercialization of agriculture, proper utilization and of resources, food security, creating opportunities, inclusive development in the rural area and positive change in overall society. The main objective of the study is to assess the strength and challenges of federal governance in Nepal. Further, the study had reviewed the existing governance status in Nepal including Local Self Governance Act (LSGA) 1999 and its impact in the country. It aims to identify the rural development approach for the proper development of the nation with need based or right based approach. The study was conducted in the descriptive and exploratory design. The secondary data were only used in the study. The major sources of data were collected from the MoFALD, Central Library of TU, CBS, CEDA library, Nepal Rasta Bank Library, NPC, Public Information Centre, World Bank, Nepal etc. Nepal is still anxious to see and enjoy "democracy dividends" - social welfare, justice, equity, and equal access to resources and power. A reflection on the above calls to question certain issues that stands as challenge(s) to democratic governance in Nepal. These issues remain critical governance problems: leadership challenges, corruption, lack of transparency, and system of electoral reforms, rising civil strife, poverty, unemployment, lack of human security and human rights.
\end{abstract}

\section{Keywords:}

Decentralization, Democracy, Federalism, Governance, Hardware and Software Development, People's Participation,

\section{Introduction}

Nepal had gone through the unitary state over the last six decades, even after democracy was successfully established against Rana oligarchy in 1951. Unfortunately, it was relapsed in 1960, when non-party Panchayat democracy was introduced by late king Mahendra and ran the country for thirty years under the active dictatorial regime. Peaceful political movement and struggles $3{ }^{*}$ Mr. Bhattarai is associated with Tribuvan University of Nepal can be corresponded atnewkopila@gmail.com 
reinstated the multiparty democracy successfully in 1991. Again the democratic system was taken over by king Gyanendra in 2005 while the country was severely inflicted with Maoist insurgency. The political parties that are supposed to have governed the state was almost messed up due to malpractices and incompetences in delivering services in one hand, and unable to tackle with the insurgency on the other gave the space for constitutional monarchy to become ambitious. So Nepal has a bitter experience of back and forth of deprivation of democratic system over the six decades, but none of the turmoil or dictatorial regime realized a necessity of change of unitary to federal system. Federalism in Nepal has been adopting as an outcome of struggle of regional and ethnic identity as well as experiences of prolong ideological dispute. It is true that when political parties formed and begun to fight for democracy.

Falgun 07, 2007is known as a remarkable day of Nepalese History in political reform. It was the dawn of the fourth Republic, a return to democratic rule after several years under the burden of military misrule which was marked by much suffering, infrastructure decay, and institutionalized corruption. Federalism is not a newly introduced concept in Nepal. There are several opportunities but also massive developmental and socio economic inequality existing among the differential providence and local level. The federal system of governance is the decentralization of powers and responsibilities to the provincial and local units. It is expected to address the desires and aspiration of the general public efficiently and effectively. In federal system the different levels of government are involved in all stages of development including policy formulation planning and implementation as well as monitoring and evaluation of the development activities (Lamichhane, 2011). Federalism is a types of government in which the power is divided between National, Provincial and Local government or other governmental units.

Local governance is the widely accepted democratic system of governing people and addressing their local-specific needs through participatory and inclusive development plans and policies, actions and programs. Local governance follows the decentralized principle of development with emphasis on the devolution of power from central authority to regional/local/sub-national level authority so as to address the problems and voice of target beneficiaries and ensure their participation in the development planning and implementation process through good governance.

\section{Research Objectives}

The main objective of the study is to assess the strength and challenges of federal governance in Nepal. Further, the study had reviewed the existing governance status in Nepal including Local Self Governance Act (LSGA) 1999 and its impact in the country. It aims to identify the rural development approach for the proper development of the nation with need based or right based approach. 


\section{Methods and Materials}

The study was conducted in the descriptive and exploratory design. The secondary data were only used in the study. The major sources of data were the MoFALD, Central Library of TU, CBS, CEDA library, Nepal Rasta Bank Library, NPC, Public Information Centre, World Bank, Nepal etc. The study was based on quantitative as well as qualitative data. Quantitative data are not analyzed by using simple statistical tools such as charts and tables. Qualitative data were analyzed in a narration. All these data were collected through document study.

\section{Analysis}

\section{Governance}

Governance is traditionally associated with government. In literature, they are frequently used interchangeably. But in the 1980s, political scientists broadened the meaning of governance as including, not just government actors, but also civil-society actors. Today, governance includes three sectors: the public sector (state actors and institutions), the private sector (households and companies), and the civil society (non-governmental organizations, community). These three sectors are said to work hand in hand in the process of governance. Local governance refers to the "exercise of authority at the community or grass root level" (Kauzya, 1990) in which various stakeholders share the power and authority in local affairs. Government and Governance are two sides of the same coin. Local government is a facilitator of network form of local governance. The government as a run way train, so the government has an opportunity to play a catalytic role in Interest based and hope based for improving social outcome for local residents.

In the $21^{\text {st }}$ century the citizen -centered local governance is adopted which is very close with people. It has been proper management for public voice with logical way. Citizen-centered local governance has been practiced in local bodies, i.e. responsive governance, responsible governance and accountable governance. In this way the people are in direct participation process in citizen centered local governance. It has been crocheted to effective service delivery, no compromise in public service, working better, costing less. The government should be accountable to its electoral system and should be transformable also. Governance refers broadly to the exercise of power through a country's economic, social, and political institutions in which institutions represent the organizational rules and regulations, formal laws and informal norms that together shape the incentives of public policy-makers, overseers and providers of public services (UNDP, 2007). The simple governance in Nepal started from Period of Mall king. However, good governance is a much recent idea of democratic governance that found expression in the detailed provisions 
of the different period of Constitution that contained the fundamental objectives and directive principles and policy of the state. Good governance became the reducible criteria for assessment of government. Good governance, among other things is participatory, transparent and accountable, effective and equitable and it promotes the rule of law. It ensures that political, social and economic priorities are based on broad agreement in society and that the voices of the poorest and the most vulnerable are heard in decision-making over the allocation of development resources.

\section{Multi-Level Governance}

Multi-level governance is that governance which is governed by different stakeholders like Federal /Province/Local Government, UN Organization, INGOs, Diplomatic Mission, International Organization, Civil society, Corporate house, Community (Local Governance). In the case of Nepal, Multi -level governance has been concerning with related stakeholder and organizations. Governance for Sustainable Human Development, the UNDP acknowledges the following as core characteristics of democratic governance: 1) Participation 2) Rule of Law 3) Transparency 4) Responsiveness 5) Consensus Orientation 6) Equity 7) Effectiveness and Efficiency 8) Accountability 9) Strategic Vision (UNDP, 2007). Good democratic governance therefore, be acknowledged as the term that symbolizes the paradigm shift of the role of governments (Khanal, 2006).

\section{Result and Discussion}

The concept of governance is not a new issue. It is as old as human civilization. It means the process of decision making and the process by which decision are implemented. Governance can be used in several contexts such as corporate governance, international governance and local governance. In decentralization and local governance, we expect to bring decision making governance, closer to the citizens/people in order to create/develop power and authority towards strengthening civic engagement in local governance process. So that we can say governance as a process or system. A system of government is one of the actors of governance. Governance frameworks are accountability, transparency/openness, integrity, and stewardship/value of public assets, efficiency, leadership, decision making and governing /organizing through laws, norms, values power and authority. It is useful to manage public resources for public welfare at large.

In the governance system of decentralization, delegating the power to local organization is called democratic decentralization. The local self-government institution including political awareness in the mind of the people and provides as opportunities to participate in politics. Governance is not government; it is frameworks of rules and regulations. Institutional practices that set limits on behavior of individual, organization and companies. Depenalization means self-control, self- 
management, self-decision making authority and self-accountability. So that it shows that the federalism also practices with those elements which are already used in local self-governance act 1999. LSGA is an old wine in new bottle with federalism.

In the case of federalism, Nepal is a country of opportunities and possibilities. Nepal has a lot of potentiality in this field and it could play a key role for economic development as well as social transformation. The Nature /Feature /Characteristics of local self-governance act-1999/2055 Regulation 2056 are fallows: Direct involvement of local people, Active participation of local body, Mobilization of human resource/capital resource, To identify the local need, Protection of cultural heritages, Maximum participation of local people in governance, Mainstreaming in development, Capacity development, Leadership development, Protection of resources, Equal distribution of resources, Democratic exercise in decision making, Political mobilization, To make responsible for local body, and To maintain balanced development. Similarly, the Output of LSGA 1999 are, Enjoyment with the fruits of democracy, Institutional development, Process of democratic governance by decentralization, Equal distribution of the fruits of development, and able to make decisions of local needs. In this way, LSGA has been created check and balance to organize the society and to keep the people and country safe. In federal governance system we should adopt different development approaches like basic needs approach, integrated rural development approach, participatory planning approach, community development approach, and rural livelihood approach which are appropriate to modify the rural life style of Nepal. We should adopt different approach on different localities of Nepal (Devkota, 2010).

\section{Re-thinking of rural development with different approach}

There has been considerable recent discussion of the changes that are taking place in rural development both in terms of the nature of the changes underway within rural economies and in terms of the approaches adopted towards rural policy. The predominant characterization is of a single change, commonly from an approach focused fundamentally on the agricultural sector towards one focused on rural territories and more diversified economic activity. Increasing food production was a first priority and other objectives, such as enhancing rural employment and services, were seen as following directly from the production support given to the agricultural sector. But during the time being the approach has changed, shifting to multisector, territorial and local approaches. The multisector policy recognizes the limits to agricultural production support and sees agriculture as one of several economic sectors through which the development objectives can be attained. The focus may still be on farming, but there is encouragement for agricultural diversification. The territorial approach recognizes the wider interactions within 
the rural economy and the importance of social and environmental as well as economic issues (Devkota, 2010).

We have so many development approaches like, basic needs approach, community development approach, and integrated rural development approach, livelihood approach, and right based approach and so on. In the rural sectors fallowing approaches should be introduced in rural areas with strong program and policy.

\section{Sectoral Approach}

This approach supports for the agricultural sector at the center and promised a means of meeting a variety of objectives for food security, rural development, farm incomes and environmental protection simultaneously through a single agricultural policy approach. In this model, agriculture represents the major sector in the rural economy and its success determines the performance of the local economy more generally. Agricultural decline promotes rural population and a decline in rural service provision. Thus, a policy to stimulate agricultural production not only supports domestic food supply, agricultural employment and farm incomes, it also deters out-migration from rural areas and supports the rural economy and service provision more generally(lbid.).

\section{Multi-Sectoral Approach}

The agricultural sector faced increasing costs in terms of dealing with the agricultural surpluses that can result from increased production and with the declining relative importance of agriculture within rural areas which can have less and less local economic impact more generally. This suggests an alternative, multisectoral approach. The relatively small contribution of agriculture to many rural areas means inevitably that other economic sectors have come to play an increasing role in the rural economy.

\section{Territorial Approach}

A truly multisectoral approach to rural development policy would look more generally and equally at the actual and potential roles for other sectors in rural areas. While located in rural areas, these will often have no economic linkages at all with agriculture. The focus thus shifts towards a more general analysis of conditions within particular types of area, or a territorial approach. In practice, this means a focus on rural areas. Rural areas can offer attractive locations for the establishment of new economic activity, often associated with the most advanced sectors of a modern economy, such as in information technology, and many areas have gained employment from the establishment of new firms and types of employment (Sharma, 2004) 


\section{The Local Development Approach.}

This is essentially a problem of information. The complexity of the problems and the reduction of traditional agricultural relationships have increased the attention given to the role of social capital and networks in the delivery of rural development. There needs to be a system whereby local circumstances can be assessed against national priorities and information disseminated to individual households and businesses on the opportunities and resources that can be made available in support of the objectives. This will not occur at a single step and the ease with which it occurs at all will depend on local institutions and the level of social capital. A sectoral approach required little institutional development at the sub-national level. However, it is the move towards a territorial and especially to a local approach. In the real meaning of the development approach 'Think globally and act locally' (UNDP, 1997).

\section{The Prospective Development approach}

Development is dynamic and never ending industry in the global context. It is the product of human brain and needs of certainty. Nepal has adopted bottom up approach in local development scheme to accelerating the national development and reduce the poverty and improvement of living standard of local people (Sharma, 2004). Science and technology have made the revolution of human development possible, in the $21^{\text {st }}$ century people's needs and aspirations have been growing with three times. It has been possible with technology, it's called hardware and in proper mobilization with human knowledge and skills which is called software. So that hardware (physical and infrastructure development) and software (skills and knowledge of human beings) are equally important in the development field. The main objective of this approach is to configure the needs for capacity building for rural development with meaningful progress and survive the rurality or beauty in rural area of Nepal.

\section{The Challenges of Critical Governance in Nepal}

\section{Leadership Challenges}

Nepal's fundamental approach to leadership is in troublesome state. In Nepal, the primary goal of assuming leadership position is self-enrichment. Whereas, Nepal's leaders have the power to educate, inspire, and provide the people with the resources to advocate for the causes they believe in, that Nepal's problem is incapable leadership and evidence on the ground has consistently shown they are incorrect. Some people however seem to disagree that leadership is not Nepal's that problem. Certainly, it is leaders and not the poor rural dwellers that are responsible for 
Nepal's underdevelopment. In every country, it is the responsibility of the leadership to protect the political, social, and economic interests of the citizens.

Leading a country involves making policies and finding solutions to problems, ensuring stability of the polity, and guiding the society to prosperity. But a large number of the political leaders of Nepal lack the vision, the passion and the character to effectively govern the state and deal with the crumbling economy. They do not have a clear understanding of their responsibilities, as some of them are insensitive to the people's sufferings. Listening is a way of showing that a leader cares about others (Devkota, 2010). Due to the fact that power belongs to the people, no political leader in the advanced democracies would function effectively without the support of the people. Thus they constantly have their ears on the ground for information (signs of shift in public opinion) that often guides them in policy formulations and implementations. The world's leading democracies are what they are today because their leaders are innovative and always searching for solutions to their social, political and economic problems. But that is not the case with Nepal; evidence of bad leadership is all over the landscape as the leaders have not gone beyond a promise for change. They are only good at drumming the country's problems without finding their solutions. The institutions and infrastructure that are the foundation of the economy are acceptable to deterioration away leading to weak economy, rising unemployment and inflation, poverty and crime.

\section{Weak Corruption Control Mechanism}

The greater challenge of Nepal facing with fraud and corruption, Corruption has, among others, have been defined as an act of requesting, offering, giving or accepting directly or indirectly a bribe or any other undue advantage or the prospect there of, which distorts the proper performance of any duty or behavior required of the recipient of the corrupt, dominant social norm and reflections on the first four decades of political independence no doubt indicate that citizens themselves are instrumental to the national decay, however, they are receptive to corrupt friendly regimes, thus, celebrating the powerful force of mal-governance and underdevelopment(Olu-Adeyemi, 2004; Sharma, 2004). Unfortunately, after years of independence, we have many corruption control mechanisms like CIAA, CIB, Internal/External Audit, CDO office, District Police office, National Vigilance Center etc. But corruption is increasing day by day from center to local level.

\section{Poor Condition of Human Rights}

Before 1990, the condition of human rights in Nepal was very poor. At present, the situation has improved. This is because democracy has only succeeded in revealing the rot of human rights 
situation. At present, fundamental rights of citizens still come under attack, despite the advent of democracy. For instance, the protection and enjoyment of the right to life and respect for human dignity is vulnerable by the non-availability of the necessary socio-economic infrastructures that can guarantee the realization and fulfilment of such rights. In the case of Nepal, violence, extortion and intimidation continued throughout the year. Numerous armed groups, largely in the Tarai, in the lowland area near the Indian border, attack civilian's government official's members of particular ethnic groups. Impunity for human right violators threats against the media arbitrary arrest are serious problems (NHRC, 2018).

\section{Reform in Electoral System}

A free and fair election brings the micro-institutions of governance closer to the people. Electoral reform is where the electoral systems we use to help the public express their desires in elections are improved. However, electoral reform is wider than just the voting system. It also includes looking to improve vote-counting procedures, eligibility to vote, constituency boundaries, the safety of voters and election workers, the financing of election and referendum campaigns, how the ballots are designed and what voting equipment is used and how candidates and political parties can be nominated and get their names onto ballots. Voting has been made too expensive for the government and the candidates. The influence of money challenges the quality of representation. Political parties must be publicly funded to increase their efficiency and transparency (Khanal, 2006).

Nepal still harbor that public money belongs to no one and that any person who has access to it should convert it into his or her personal use. Corruption permeates every sector of the Nepalese society, 'similarly, electoral corruption is prevalent. This is a situation that includes the purchase of votes with money, promises of office or special favors, force, intimidation, and interference with freedom of election, sale of votes, killing and maiming of people in the name of election, and a situation where losers end up as the winners in elections, and votes turn up in areas where votes were not cast.

\section{Civil friction}

Nepal's continued political instability and weak rule of law after the civil war, have led to the rise of violent clashes among politically affiliated armed groups and criminal activities by gangs and organized criminal groups in urban areas. In this way people are always unsafe and they are frustrated by situation of the country. Development is like an earning industry for the developing country. Earning purpose of the political leaders in the nation and burden of taxes to the people. 
It is a measuring scale of weak service delivery mechanism. Good governance is especially good quality of human characteristics and dignified life style with meaning and commitment (Badal, 2018). These characters are difficult to get.

\section{Conclusion}

Federalism does not merely mean autonomy or self-rule; it also means collaboration and shared-rule. Vertical power sharing among the tiers of the government is the core of any federal arrangement. Negligence in the power sharing among the tiers of the government leads towards further chaos in the country sooner or later. The entrenchment of local government in the constitution and laws would not be meaningful if the central government would be able to arbitrarily intervene in the local decision-making and reverse decisions made by the local and provincial governments

The system of federalism is formally introduced in first time in Nepal. The federal governance should focus on local issues like primary education, rural road, irrigation facility, basic health service, livestock service, easily access to market etc. There are serious concerns over mismanagement of the local development funds with allegation of corruption, lack of transparency and accountability and other questionable governance criteria. The constitutional spirit of inter-government cooperation, coordination and dialogue will help remove the friction among the federal, provinces and local level government. The government should address the major governance issues; social, cultural economic, political, historic and structural has led to increased concern of the people.

The difficulties the law enforcement agencies face in dealing with the increasing crimes and human right abuses continue to worry the people of Nepal. The media almost daily carry news of serious crimes in the country. This deteriorating law and order and the economic problems, should be a cause of concern for the government and other political leaders. Government must provide effective service delivery in the federal governance at local level. However, a link of other performance system is also needed. Effective local governance system plays a vital role in economic development and social justice.

\section{References}

Badal, B. P. (2018). Alternative rural development: Social justice, equity, self-reliance, and third worldism, Research Nepal Journal of Development Studies, 1.1, 1-18 
Bajracharya, S. M. (2068) Good Governance: Empowering People "PAAN Journal vol. 21 and 22 Kathmandu Public Administration Association of Nepal.

Bhatta, B.D. (1990), Decentralization in Nepal, New Delhi, Reliance Publishing House.

Cheema, G. S (2014). Toward effective local governance: Key Issues.

Devkota, K. L (2010). Performance based grant system to the local bodies of Nepal: A good practice for the grant allocation. The Economic journal of Nepal, Vol, 33.

Joshi, K. B. (2065, Local Government and Performance based Funding in Nepal Kathmandu, CEMIDNepal

Kauzya, John-Mary, (1990). Some Positive Effects of Corruption, Journal of the Uganda Management Institute.

Khanal, R. (2006). Local Governance in Nepal, Democracy at Grassroots, Smriti Books, Kopundol, Lalitpur.

Lamichhane, H.R. (2011). Fiscal Federalism and local finance in Nepal M Phil Thesis. Submitted to Economics Department.Tribhuwan University Kirtipur.

NHRC. (2018). Human Right Report 2018, National Human Right Commission, Pulchok Lalitpur.

Shah, A. \& Shah, S. (2006). "The New Vision of Local Governance and the Evolving Roles of Local government". In Public sector governance and 155 accountability series, Local Governance in Developing countries, ed. Shah, Anwar, the World Bank, Washington D.C.

Sharma, P. (2004) Prospect of local development of planning in Nepal, Neplese Journal of Development and Rural Studies. Vol.1 No.1 Jan-June 2004. Central Department of Rural Development, T U, Kirtipur.

Shreshtha, T. N. (1999). The implementation of decentralization scheme in Nepal: An assessment and lessons for future, Modern Printing Press Kathmandu, Nepal

UCLG, (2010). Local government finance: challenges of the 21st century, second global report of decentralization and local democracy, united cities and local government.

UNCDF, (2004). Local Government Initiative: Pro-Poor Infrastructure and Service Delivery in Rural Asia. In A synthesis of case studies, ed. Roger Shotten, February 2004

UNDP, (1997). Good governance for Sustainable Human Development, A UNDP, policy document, New York. 